\title{
Cadmium Toxicity in Plants and Role of Mineral Nutrients in Its Alleviation
}

\author{
Rahat Nazar, Noushina Iqbal, Asim Masood, M. Iqbal R. Khan, Shabina Syeed, Nafees A. Khan*
}

Plant Physiology and Biochemistry Lab, Department of Botany, Aligarh Muslim University, Aligarh, India.

Email: *naf9@lycos.com

Received July $13^{\text {th }}, 2012$; revised August $15^{\text {th }}, 2012$; accepted August $30^{\text {th }}, 2012$

\begin{abstract}
Cadmium (Cd) is a toxic heavy metal that enters the environment through various anthropogenic sources, and inhibits plant growth and development. Cadmium toxicity may result from disturbance in plant metabolism as a consequence of disturbance in the uptake and translocation of mineral nutrients. Plant nutrients and $\mathrm{Cd}$ compete for the same transporters and, therefore, presence of $\mathrm{Cd}$ results in mineral nutrients deficiency. The optimization of mineral nutrients under $\mathrm{Cd}$ stress could reduce $\mathrm{Cd}$ toxicity by greater availability at the transport site resulting in reduced accumulation of $\mathrm{Cd}$, and could also alleviate $\mathrm{Cd}$-induced toxic effects by enhancing biochemical reactions and physiological processes in plants. In the present review the role of plant macro, micro and beneficial elements in alleviating $\mathrm{Cd}$ stress in crop plants is discussed.
\end{abstract}

Keywords: Antioxidant Enzymes; Cadmium Toxicity; Mineral Nutrition; Oxidative Stress

\section{Introduction}

The increased dependence of agriculture on chemical fertilizers and sewage wastewater irrigation and rapid industrialization has added toxic metals to agricultural soils causing harmful effects on soil-plant environment system. Cadmium (Cd) is among the metal contamination, and is considered as a major environmental concern to the agricultural system as its residence time in soil is over thousands years [1]. Cadmium has been placed at seventh rank among the top toxins. Cadmium concentrations of uncontaminated soils are usually below $0.5 \mathrm{mg} \cdot \mathrm{kg}^{-1}$, but can reach up to $3.0 \mathrm{mg} \cdot \mathrm{kg}^{-1}$ depending on the soil parent materials [2]. Although Cd is a non-essential element for crop plants, it is easily taken up by plants growing on Cd-supplemented or Cd-contaminated soils, entering food chain and causing damage to plant and human health. It has been reported that mean concentration of $\mathrm{Cd}$ ranges from 0.013 to $0.22 \mathrm{mg} \cdot \mathrm{kg}^{-1}$ for cereal grains, 0.07 to 0.27 $\mathrm{mg} \cdot \mathrm{kg}^{-1}$ for grasses, and 0.08 to $0.28 \mathrm{mg} \cdot \mathrm{kg}^{-1}$ for legumes [3]. Some phosphatic fertilizers and phosphorites contain high concentrations of $\mathrm{Cd}\left(4.77 \mu \mathrm{g} \cdot \mathrm{g}^{-1}\right)$ and are considered as the potential cause of increasing $\mathrm{Cd}$ contamination in rice [4].

The accumulation of $\mathrm{Cd}$ in plants may cause several physiological, biochemical and structural changes [5-7]. Cadmium accumulation alters mineral nutrients uptake,

${ }^{*}$ Corresponding author. inhibits stomatal opening by interacting with the water balance of plant [8], disturbs the Calvin cycle enzymes, photosynthesis, carbohydrate metabolism $[9,10]$, changes the antioxidant metabolism [6], and lowers the crop productivity [1]. As $\mathrm{Cd}$ is unable to participate directly in biological redox reactions, it induces oxidative stress via different indirect mechanisms. Once inside the plant, $\mathrm{Cd}$ stimulates the activity of NADPH oxidases, resulting in extracellular superoxide, $\mathrm{H}_{2} \mathrm{O}_{2}$ accumulation and lipid peroxidation and oxidative burst [11]. Moreover, Cd stimulates production of phytochelatins by increased phytochelatin synthase activity. The production of phytochelatins results in chelation of $\mathrm{Cd}$ by sequestering the phytochelatin-Cd conjugant in vacuoles decreasing free $\mathrm{Cd}$ concentration. Since phytochelatins are oligomers of reduced glutathione (GSH), this can lead to depletion of the GSH pool an important metabolite in maintaining the cellular redox balance.

In soil-plant relationship, $\mathrm{Cd}$ may influence physiological processes and biochemical mechanisms primarily by affecting concentration and functions of mineral nutrients. Cadmium has been shown to interact with the availability of nutrient elements [5] and also some of these nutrients have protective role against the toxic effects of $\mathrm{Cd}$ stress [5,6]. Having recognized the importance of mineral nutrients for agricultural systems and the adverse effects of $\mathrm{Cd}$ on plants, it is necessary to understand the interaction between nutrients to optimize 
mineral nutrients for Cd stress alleviation. Recently, Sarwar et al. [12] have shown the interaction of mineral nutrients in reducing $\mathrm{Cd}$ accumulation, and important progress has been made in elucidating the roles of essential and beneficial plant elements in $\mathrm{Cd}$ stress alleviation. Therefore, the objective of this article was to focus primarily on the current understanding of the importance of macro, micro and beneficial elements in the alleviation of $\mathrm{Cd}$ toxicity and how other nutrient availability may reduce the accumulation of $\mathrm{Cd}$ in plants, reducing its toxicity.

\section{Cadmium Accumulation and Toxicity in Plants}

It has been reported that expression of $\mathrm{ABC}$ transporters involved in $\mathrm{Cd}$ accumulation in the vacuole or natural resistance-associated macrophage protein (NRAMP) involved in the transport of divalent cations [13], was preferentially induced in plants exposed to $10 \mu \mathrm{M} \mathrm{Cd}$, but to a lesser extent in plants treated with $100 \mu \mathrm{M} \mathrm{Cd}$. Two metabolic enzymes that seem to play a role in cellular responses to several abiotic stresses: alanine aminotransferase and hexokinase [14] were also induced by $10 \mu \mathrm{M}$ $\mathrm{Cd}$. The former is an important enzyme for glutamate (Glu) synthesis, a precursor of glutamylcysteine and GSH. The available information on the negative effects of $\mathrm{Cd}$ in soil on several physiological processes led to work on induction of $\mathrm{Cd}$ tolerance mechanisms in plants. The plant-specific adverse effect of $\mathrm{Cd}$ on membranes function is by binding of $\mathrm{Cd}$ to protein sulfhydryl groups of enzymes. The activity of $\mathrm{H}^{+}$-ATPase, participating in the uptake of elements by roots, in the cell membrane of roots of papilionaceous plants has been found significantly lower than in the Cd-tolerant cucurbitaceous plants [15]. It has been shown that Cd produces DNA strand breaks, DNA-protein crosslinks, oxidative DNA damage, chromosomal aberrations, dysregulation of gene expression resulting in enhanced proliferation, depressed apoptosis, and/or altered DNA repair [16]. Ünyayar et al. [17] reported that $\mathrm{Cd}$ is both cytotoxic and genotoxic in Vicia faba and leads to sister chromatid exchange (SCE), an indicator of persistent DNA damage. However, antioxidative enzymes and antioxidants play important roles in the protection of Cd-exposed $V$. faba from genotoxic effects of this metal. Further studies of the mechanism(s) of Cd-induced SCEs in relation to the responses of the antioxidative systems may allow new insights into how the mutagenic effects of $\mathrm{Cd}$ may be modified by plant adaptation mechanisms in Cd-contaminated environments. Intracellular signaling and apoptotic pathways are clearly impaired after $\mathrm{Cd}$ exposure.

Soil contamination with $\mathrm{Cd}$ affects properties of soil directly surrounding the roots (soil rhizosphere) and in- fluences the uptake of essential elements required for proper plant growth and development. The effect of $\mathrm{Cd}$ on nutrient uptake is determined by both the degree of soil contamination and the plant species and organs, which have different tolerance to toxic heavy metals. Recently, Ueno et al. [18] examined genotypic variations in shoot $\mathrm{Cd}$ concentration in 146 rice accessions from rice corecollection and found a large variation in the shoot $\mathrm{Cd}$ accumulation and $\mathrm{Cd}$ tolerance. There are significant differences in $\mathrm{Cd}$ tolerance among species and varieties, but the contradictions exist between the results of different experiments. These differences may be attributed to the inherent differential capacity of different species and varieties for $\mathrm{Cd}$ accumulation and partitioning in root and shoot, and also on the ability to restrict $\mathrm{Cd}$ in roots.

The partitioning of $\mathrm{Cd}$ to different plant organs plays important role in toxicity of $\mathrm{Cd}$ to plants. The amount of $\mathrm{Cd}$ that accumulates in plant is limited by several factors including: 1) Cd bioavailability within the rhizosphere; 2) Rates of Cd transport into roots via either the apoplastic or symplastic pathways; 3) The proportion of $\mathrm{Cd}$ fixed within roots as a $\mathrm{Cd}$ - phytochelatin complex and accumulated within the vacuole; and 4) Rates of xylem loading and translocation of $\mathrm{Cd}$. Cation-exchange capacity (CEC) of the root cell walls may also be an important factor influencing the net uptake of metals. A high CEC implies a high metal adsorption in the cell walls, making the metal ions more available for membrane transport as well as decreasing the metal efflux. High CEC may also increase the metal content in the cytoplasm and thus affect the tolerance to the metal.

A putative chromatin remodeling factor, named OXS3, was recently identified in screening for $\mathrm{Cd}$ tolerance of a B. juncea cDNA library in Schizosaccharomyces pombe [19]. An OXS3 mutant was hypersensitive to $\mathrm{Cd}$ and its over-expression improved Cd tolerance. Verbruggen et al. [20] postulated that OXS3 might protect DNA or alter its transcriptional selectivity. While most $\mathrm{Cd}$ is chelated before its transport to the vacuole, $\mathrm{Cd}$ can be directly transported into the vacuoles by $\mathrm{Cd}$ /proton antiporters like CAX2 and CAX4 and possibly also by MHX [21]. Korenkov et al. [21] have reported that the over-expression of AtCAX2 or AtCAX4 in tobacco enhances $\mathrm{Cd}$ and zinc $(\mathrm{Zn})$ transport into root tonoplast vesicles and enhances $\mathrm{Cd}$ accumulation in roots of plants exposed to $\mathrm{Cd}$.

The interactions between heavy metals and the properties of soil play an important impact on the environment through their decreasing effect on the bioavailability of heavy metals, thus favorably affecting the environment. It has been demonstrated that some plants can actively or passively change $\mathrm{H}^{+}$excretion under heavy metal stress. Such root-induced changes of rhizosphere $\mathrm{pH}$ play a major role in the bioavailability of many $\mathrm{pH}$ dependent nutrients, but also potentially toxic metals and a range of 
trace metals [22]. Uptake of Cd by root from soil depends on the soil factors such as $\mathrm{Cd}$ concentration in soil, soil $\mathrm{pH}$ and level of organic matter. The interaction between nutrients, heavy metal and soil may occur at the level of plant and/or in the soil. In soil, nutrients and metal interact at the level of precipitation, surface absorption and formation of complexes with organic compounds [23]. Rhizosphere is an important environmental interface connecting plant roots and soil. The influence of root exudates on $\mathrm{Cd}$ bioavailability and toxicity is a consequence of change in the rhizosphere $\mathrm{pH}$, redox potential and the number and activity of rhizospheric microbes, and the capacity for chelating with $\mathrm{Cd}$ ions. Some motile physiological changes would take place when plants are grown under heavy metal conditions, and then make a series of physical and chemical reactions of heavy metals in rhizosphere to affect their transfer in soil-plant system, which may be beneficial to decrease the metal availability and its absorption by plants. Therefore, it is understandable that the study of root rhizosphere has been one of the most important issues in toxicity and tolerance of metals. Mench and Martin [24] reported that low molecular weight of organic acids secreted by roots played an important role in solubility and availability of heavy metals, and $\mathrm{Cd}$ availability would be reduced if $\mathrm{Cd}$ bound into $\mathrm{Cd}$ chelate complex with root secretion. The roots of some plants, such as wheat and buckwheat, excrete organic acid such as oxalic acid, malic acid and citric acid that can chelate with $\mathrm{Cd}$ to prevent its entrance into roots. In addition, the combination of organic phosphate acids and $\mathrm{Cd}$ ions would produce cadmium phosphate complexes unavailable to plants. An overview of absorption of Cd present in soil; its transportation, accumulation and detoxification has been shown in Figure 1.

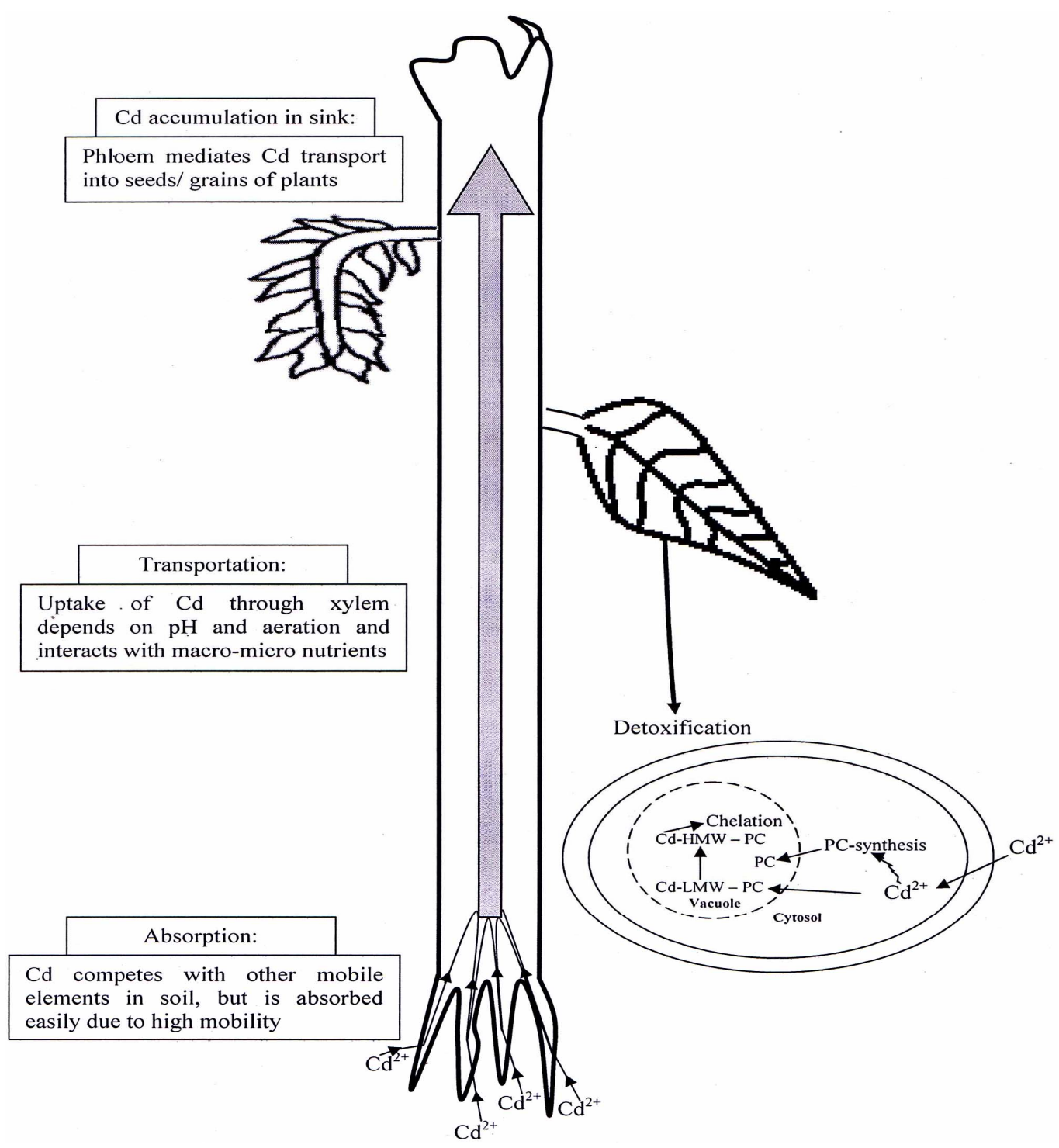

Figure 1. An overview of Cd absorption, transportation, accumulation and detoxification in plants. 


\section{Effects of Cadmium on Nutrients Transport, Accumulation, and Physiological and Molecular Processes}

The transient deficiencies of nutrients may occur as a consequence of a combination of spatial and temporal variations in plant nutrient demand and supply, which is influenced by the relative mobility of nutrients in plant. The movement of mineral elements to the root surface depends on: 1) Diffusion of elements along the concentration gradient formed due to uptake generating depletion of the element in the root vicinity; 2) Root interception, where soil volume is displaced by root volume due to root growth; and 3) Mass flow, transport of bulk soil solution along the water potential gradient (driven by transpiration) [25].

The inorganic nutrients required for plant growth can be provided to growing tissues either in the xylem, driven by transpirational water flow, or in the phloem, associated with the sink-driven movement of organic solutes from source to sink tissues. The relative contribution of phloem and xylem transport to the supply of nutrient elements varies from species to species and differs for each element. The nutrients such as nitrogen $(\mathrm{N})$, phosphorus $(\mathrm{P}), \mathrm{K}$, sulfur $(\mathrm{S})$, and magnesium $(\mathrm{Mg})$ are readily transported in either the xylem or phloem (phloemmobile nutrients), whereas calcium (Ca), and, in non-sugar alcohol species, boron (B) have limited mobility and can only be supplied to growing tissues in the xylem (phloemimmobile nutrients). The ability of a plant species to survive or to yield optimally during a period of nutrient deficiency is, therefore, a consequence of both its ability to obtain nutrients from the soil under limiting conditions and the extent to which the nutrients can be supplied through redistribution from other plant tissues. Cadmium being a divalent cation may compete with $\mathrm{Ca}, \mathrm{Mg}$ or iron (Fe) in their transport across membranes [26]. It is taken up by plants via cation transport systems normally involved in the uptake of essential elements, such as members of ZIP and NRAMP families or $\mathrm{Ca}$ channels and transporters [27]. The competition between nutrients and toxic metal in the plant for binding sites in different compartments, such as cell wall, plasma membrane, and the cell may influence the distribution of toxic metal [28]. Cadmium entry through the $\mathrm{Ca}$ channel in the leaves disturbs the plant-water relationship [27], causing stomatal closure in many plants, leading to lower transpiration rate, and inhibition of photosynthesis through an adverse effect on chlorophyll metabolism. This subsequently leads to growth inhibition and imbalance in the nutrient level. The decrease of $\mathrm{Mn}, \mathrm{Fe}, \mathrm{Mg}, \mathrm{S}$ and $\mathrm{P}$ concentrations in leaves of Cd-sensitive cultivars under $\mathrm{Cd}$ stress has been shown to be the key reason for the restraint of leaf photosynthesis, and the decrease of cabbage growth [29].
Cd-induced inhibition of photosynthesis has also been attributed to an inhibition of the activity of key enzymes of the Calvin cycle and the photosynthetic electron transport chain in rice [30], and inhibition occurred at the uptake level or in translocation of nutrients. Cadmium may interfere with the nutrient uptake by altering the plasmamembrane permeability, leakage of nutrients through plasma membrane [31] and affect the element-transport processes across the membrane [32].

An excess Cd supply increased macronutrient and decreased micronutrient concentrations in the Aeluropus littoralis [33]. Aina et al. [34] reported that high percentage of polymorphism in rice DNA following exposure to $\mathrm{Cd}$. This might be mainly related to DNA breaks which were supported by the absence of preferential mutation sites in the rice genome as suggested by the random distribution of DNA polymorphic bands. They also reported that although high concentration of Cd damages DNA, the low dose of Cd avoid or repair, at least in part, DNA breaks and induced changes in metabolic enzymes and activated defense mechanisms by the induction of transporters and proteins involved in the degradation of oxidatively modified proteins. Gonçalves et al. [35] showed that $\mathrm{Cd}$ decreased the macronutrient and micronutrient contents in the in vitro cultured potato plantlets in both roots and shoots. In contrast, the macronutrient and micronutrient contents in the hydroponically grown plantlets were generally not affected by $\mathrm{Cd}$ and that the influence of $\mathrm{Cd}$ on nutrient content in potato varied according to the level of $\mathrm{Cd}$, potato cultivar, plant organ, essential element and growth medium. They reported that excessive $\mathrm{Cd}$ accumulation may affect the uptake and distribution of certain nutrients in the potato cultivars, and consequently may be responsible for mineral disturbances and depression of plantlet growth.

Members of the ZIP gene family, a novel metal transporter family first identified in plants, are capable of transporting a variety of cations, including $\mathrm{Cd}, \mathrm{Fe}, \mathrm{Mn}$ and $\mathrm{Zn}$. Information on where in the plant each of the ZIP transporters functions and how each is controlled in response to nutrient availability may allow the manipulation of plant mineral status for creating food crops with enhanced mineral content, and developing crops that bioaccumulate or exclude toxic metals [36]. Dong et al. [37] through regression analysis showed that there was a significantly negative correlation between $\mathrm{Cd}$ and $\mathrm{Mn}$, implying the antagonistic effect of $\mathrm{Cd}$ on $\mathrm{Mn}$ absorption and translocation. The correlation between $\mathrm{Cd}$ and $\mathrm{Zn}$, copper $(\mathrm{Cu})$ and $\mathrm{Fe}$ was inconsistent among leaves, stems and roots. Cadmium alters the conformation of proteins, for example enzymes, transporters or regulator proteins, due to its strong affinity as ligand to sulfhydryl and carboxylic groups [38]. The $\mathrm{Cd}$ exposure increases the expressions of the exogenous and the endogenous Fe-de- 
ficiency responsive genes, HvIDS2pro::GUS, NtFRO1 and NtIRT1 in the roots [39]. Cadmium damages DNA and $\mathrm{Zn}$ probably modulates the protection of DNA from $\mathrm{Cd}$-induced damage either by inhibition of $\mathrm{Ca} / \mathrm{Mg}$-dependent endonuclease or by inhibiting metal catalyzed oxidative damage through $\mathrm{OH}$ attack on either the DNA or protein both by -SH group protection and inhibition of redox cycling of the associated metal ions thereby preventing the generation of covalent linkages such as thymine-cysteine adducts [40]. Three basic helix-loop-helix transcription factors, FIT, AtbHLH38 and AtbHLH39, involved in $\mathrm{Fe}$ homeostasis in plants also play important roles in $\mathrm{Cd}$ tolerance. The gene expression analysis showed that the expression of FIT, AtbHLH38 and AtbHLH39 was up-regulated in the roots of plants treated with $\mathrm{Cd}$. The plants overexpressing AtbHLH39, double-overexpressing FIT/AtbHLH38 and FIT/AtbHLH39 exhibited more tolerance to $\mathrm{Cd}$ exposure than wild type, whereas no $\mathrm{Cd}$ tolerance was observed in plants overexpressing either AtbHLH38 or FIT. Further analysis revealed that co-overexpression of FIT with AtbHLH38 or AtbHLH39 constitutively activated the expression of HMA3, MTP3, IRT2 and IREG2, which are involved in the heavy metal detoxification in Arabidopsis. Moreover, co-overexpression of FIT with AtbHLH38 or AtbHLH39 also enhanced the expression of NAS1 and NAS2, resulting in the accumulation of nicotiananamine, a crucial chelator for $\mathrm{Fe}$ transportation and homeostasis. Thus maintenance of high $\mathrm{Fe}$ content in shoot under $\mathrm{Cd}$ exposure alleviates the Cd toxicity [41]. Phytolacca americana (pokeweed) is a perennial herb that was found to be a good $\mathrm{Mn}$ and $\mathrm{Cd}$ hyperaccumulator with great potential for remediation of $\mathrm{Mn}$ and $\mathrm{Cd}$ contaminated soils. In the presence of $\mathrm{Cd}$, adding $\mathrm{Mn}$ to the solution significantly improved the plant growth and reduced the concentrations of $\mathrm{Cd}$ in all organs of the plant [42].

Cadmium negatively influences the structural integrity of DNA which was identified utilizing the principle of the formation of a fluorescent complex between double-stranded DNA and ethidium bromide (EB) [43]. Exposure to $10 \mu \mathrm{M} \mathrm{Cd}$ results in a distinct loss of fluorescence due to the decreased binding of EB with DNA and direct binding of $\mathrm{Cd}$ to DNA bases (specifically guanine, adenosine and thymine).

Different transporters are involved in the translocation of nutrients into the aerial part of the plant at different levels, and $\mathrm{Cd}$ can inhibit these transporters. Toxic heavy metals compete with the transport systems operating for micronutrient uptake, and this occurs by using the same transmembrane carriers used for the uptake of $\mathrm{Ca}^{2+}, \mathrm{Fe}^{2+}$, $\mathrm{Mg}^{2+}, \mathrm{Cu}^{2+}$ and $\mathrm{Zn}^{2+}$ ions [44,45]. Due to its high mobility and water solubility, $\mathrm{Cd}$ readily enters the roots through the cortical tissue and can reach the xylem via an apoplastic and/or symplastic pathway, complexed to organic acids or phytochelatins [46]. Once loaded into the tracheary elements, $\mathrm{Cd}$ complexes are transported within the plant following the water stream. It has been shown that $\mathrm{Cd}$ accumulation in developing fruits could occur via phloemmediated transport, implicating a systemic diffusion of the heavy metals into the plant [47]. Another important toxicity mechanism is due to the chemical similarity between $\mathrm{Cd}^{2+}$ and functionally active ions situated in active sites of enzymes and signaling components. Thus, $\mathrm{Cd}^{2+}$ ions can interfere with homeostatic pathways for essential metal ions [44] and the displacement of divalent cations, such as $\mathrm{Zn}$ and $\mathrm{Fe}$, from proteins could cause the release of "free" ions, which might trigger oxidative injuries via free $\mathrm{Fe} / \mathrm{Cu}$-catalyzed Fenton reaction [48]. Land plants possess a highly effective metal ions uptake system that allows the acquisition of metal ions and other inorganic nutrients from soil by plant roots. Therefore, metal transporters, situated in the tonoplast or plasmamembrane, play a central role in the maintenance of metal homeostasis within physiological limits. In fact, Cd tolerance is correlated with its extrusion or intracellular compartmentalization mediated by the activation of specific transport processes.

The transport protein involved in metal transport may be general or specific. The family of NRAMP metal ion transporters represents an important group of transmembrane protein involved in metal transport and homeostasis and are considered as "general metal ion transporters" due to their ability to transport $\mathrm{Mn}^{2+}, \mathrm{Zn}^{2+}, \mathrm{Cu}^{2+}, \mathrm{Fe}^{2+}$, $\mathrm{Cd}^{2+}$, nickel $\left(\mathrm{Ni}^{2+}\right)$ and cobalt $\left(\mathrm{Co}^{2+}\right)$ ions [49]. Some transport proteins might be involved in uptake and transport of $\mathrm{Zn}$ as well as $\mathrm{Cd}[50]$. Concerning efflux systems, metal transporters P1B-ATPases (HMA) translocate metal ions out of the cytoplasm (both outside the plasma membrane and into the vacuole) hydrolyzing ATP. Export metaltransporters are more selective than import-trans- porters. Indeed, HMA members (e.g. HMA2, HMA3 and HMA4) export $\mathrm{Zn}$ and $\mathrm{Cd}$ exclusively [51]. Recent works highlighted that members of this family (AhHMA4, AhHMA3 and TcHMA4 deriving from hyperaccumulator species $A$. halleri and T. caerulescens) are able to confer $\mathrm{Cd}$ or $\mathrm{Zn}$ tolerance when expressed in yeast $[45,52]$. Therefore, it has been proposed that AhHMA4, TcHMA4 and probably AtHMA4, its homolog in A. thaliana, may contribute to $\mathrm{Cd}$ and $\mathrm{Zn}$ homeostasis extruding the metal ions from the cytosolic compartment [51]. The $\mathrm{Zn} / \mathrm{Cd}$ transporting ATPase HMA2 and HMA4, essential for root to shoot translocation of $\mathrm{Zn}$ can also transport $\mathrm{Cd}$ [50]. Cadmium uptake via IRT1 may transport $\mathrm{Cd}$ and might prove to be useful in Cd removal from contaminated soil. Arabidopsis IRT1, which belongs to the ZIP (ZRT = Zinc Regulated Transporter/IRT Related Proteins) family of transporters, has a broad substrate range and transports $\mathrm{Fe}$, $\mathrm{Mn}, \mathrm{Zn}$, and possibly Cd [53,54]. 
Besides, members of the "cation diffusion facilitator" transporter group seem to mediate vacuolar sequestration, storage and transport of metal ions from the cytoplasm to the outer compartment and have been characterized in both prokaryotes and eukaryotes and can transport across membranes divalent metal cations such as $\mathrm{Zn}, \mathrm{Cd}, \mathrm{Co}, \mathrm{Fe}$, $\mathrm{Ni}$ or Mn [55]. Natural resistance-associated macrophage protein3 (NRAMP3) and NRAMP4 are responsible for $\mathrm{Cd}$ efflux from the vacuole [56]. Their over-expression increased Cd sensitivity in Arabidopsis as a result of the impairment of Fe homeostasis, as NRAMP3 and NRAMP4 are responsible for the release of vacuolar Fe. Plant nutrients also help to sequester $\mathrm{Cd}$ in vegetative parts by production of phytochelatins and avoid $\mathrm{Cd}$ accumulation in grains.

\section{Plant Mineral Nutrients in Alleviation of Cadmium Toxicity}

A balance of inorganic nutrients is required by plants for maximum growth and development under optimal and stressful environments. Mineral deficiencies or imbalances and depression of plant growth can result from excessive $\mathrm{Cd}$ toxicity that affects the rate of uptake and distribution of certain nutrients in plants. To reverse the negative effect of Cd stress, plants need to either inhibit its accumulation or enhance its tolerance capacity to $\mathrm{Cd}$ for survival. The severity of $\mathrm{Cd}$ toxicity, however, can be reduced through the optimization of these nutrients. Sufficient availability of nutrients may reduce the accumulation of a metal in plants and decrease its toxicity by inducing several physiological processes. Mineral nutrients-induced physiological processes for alleviation of $\mathrm{Cd}$ stress are summarized in (Tables $\mathbf{1}$ and 2). The activity of antioxidant system maintains the redox status of plant cell, removes reactive oxygen species (ROS), mitigates Cd-induced stress at different level of their targeting sites and maintains functionality of photosynthetic system, resulting in increased plant dry mass, growth and yield (Figure 2). The potential of some of the important plant macro, micro and beneficial elements in alleviating Cd toxicity in plants is summarized below.

Table 1. Macro nutrients-induced physiological responses for alleviation of Cd stress.

\begin{tabular}{cccc}
\hline Nutrients & Plant species & Physiological response for Cd alleviation & References \\
\hline $\mathrm{N}$ & Helianthus annuus & Increases investment in rubisco protein & {$[91]$} \\
& Triticum aestivum & Reduces Cd accumulation & {$[92]$} \\
$\mathrm{P}$ & Trema micrantha & Reduces Cd concentration & {$[93]$} \\
& Elodea nuttallii & Increases activities of peroxidases and catalases & {$[62]$} \\
$\mathrm{K}$ & Brassica juncea & Inhibits Cd uptake from the medium & {$[65]$} \\
$\mathrm{S}$ & Oryza sativa & Detoxifies Cd by inducing Cd-binding proteins & {$[94]$} \\
& Triticum aesitivum & Increases ATP-S activity & {$[5]$} \\
& Brassica juncea & Increases GSH content & {$[6,68]$} \\
$\mathrm{Ca}$ & Arabidopsis thaliana & Decreases Cd content & {$[77]$} \\
& Trifolium repens & Decreases Cd accumulation & {$[78]$} \\
$\mathrm{Mg}$ & Oryza sativa L. & Decreases genes expression for Cd transport & {$[80]$} \\
\hline
\end{tabular}

Table 2. Micro nutrients and beneficial elements-induced physiological responses for alleviation of Cd stress.

\begin{tabular}{|c|c|c|c|}
\hline Nutrients & Plant species & Physiological response for Cd alleviation & References \\
\hline \multirow[t]{2}{*}{$\mathrm{Fe}$} & Brassica juncea & Fe stabilizes complex proteins and provide stability to chloroplast under $\mathrm{Cd}$ stress & {$[84]$} \\
\hline & Lupinus albus & Protects photosynthetic tissues & {$[86]$} \\
\hline \multirow[t]{4}{*}{$\mathrm{Zn}$} & Triticum durum & Addition of $\mathrm{Zn}$ to soil reduced crop $\mathrm{Cd}$ concentrations & {$[95]$} \\
\hline & Oryza sativa & Inhibits Cd uptake & {$[30]$} \\
\hline & Brassica chinensis & Suppresses Cd uptake and root-to-shoot transport & {$[90]$} \\
\hline & Arachis hypogaea & Reduces shoot $\mathrm{Cd}$ accumulation and a stimulation of antioxidative enzymes & {$[10]$} \\
\hline $\mathrm{Se}$ & Brassica napus & Inhibits $\mathrm{Cd}$ accumulation in cells and activates antioxidant system & [87] \\
\hline
\end{tabular}




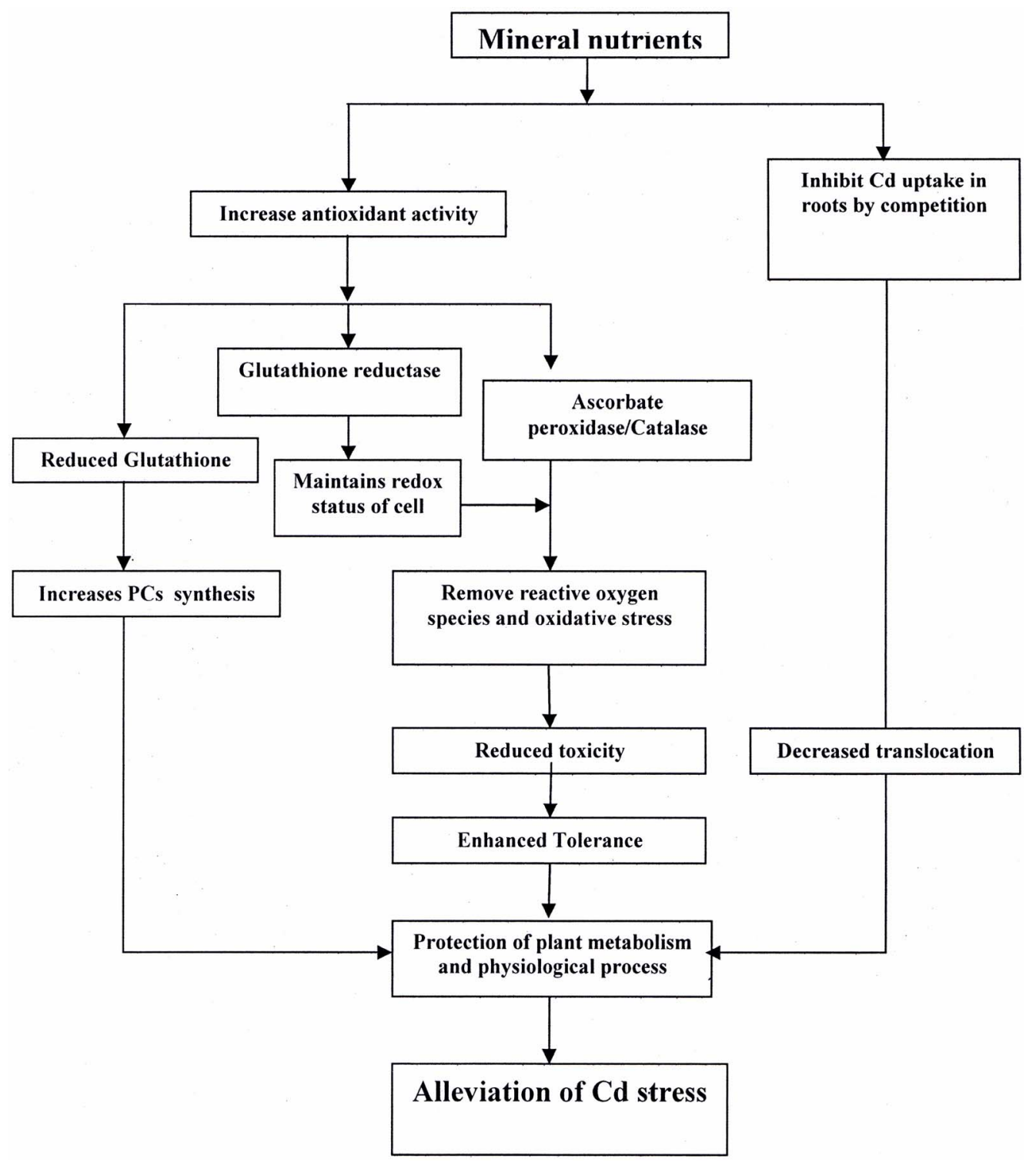

Figure 2. Physiological and metabolic processes associated with Cd stress alleviation in plants.

\subsection{Macro Nutrients}

Primary nutrient elements $(\mathrm{N}, \mathrm{P}, \mathrm{K})$ are integral part of our agricultural system for optimizing crop productivity and also for sustainable agriculture. Nitrogen supplementation to Cd-stressed plant leads to an enhanced Cd tolerance in plants by increasing the photosynthetic capacity of plants. Pankovic et al. [57] have shown that optimal N $(7.5 \mathrm{mM})$ supply decreased the inhibitory effects of $\mathrm{Cd}$ on photosynthesis of sunflower plants by increasing ribulose 1,5-bisphosphate carboxylase (Rubisco) activity or by the increase in soluble protein content. The alleviation of $\mathrm{Cd}$ toxicity by $\mathrm{N}$ application also depends on the $\mathrm{N}$ source [58]. The application of $\mathrm{NH}_{4}^{+}-\mathrm{N}$ reduces the $\mathrm{Cd}$ concentration in leaves of rice plant under $100 \mathrm{mg} \cdot \mathrm{kg}^{-1}$ $\mathrm{Cd}$, while $\mathrm{NO}_{3}^{-}-\mathrm{N}$ increases it, suggesting an antagonistic effect between $\mathrm{NH}_{4}^{+}-\mathrm{N}$ and $\mathrm{Cd}$ and a synergistic effect between $\mathrm{NO}_{3}^{-}-\mathrm{N}$ and $\mathrm{Cd}$ [58]. Upon exposure to $\mathrm{Cd}$, plants often synthesize a set of N-containing metabolites through $\mathrm{N}$ metabolism, such as proline, GSH and phytochelatins, which play a significant role in $\mathrm{Cd}$ tolerance of plants [59]. The other reason for $\mathrm{N}$-induced alleviation of $\mathrm{Cd}$ toxicity has been suggested as the increased biomass production by increasing the photosynthetic rate with $\mathrm{N}$ application. The increased biomass production sequesters more $\mathrm{Cd}$ in vegetative parts and very little moves into the grain. Recently, Zhu et al. [60] have shown that $\mathrm{N}$ fertilizer in the form of $16 \mathrm{mM}\left(\mathrm{NH}_{4}\right)_{2} \mathrm{SO}_{4}$ was effective in $\mathrm{Cd}$ alleviation in Sedum. The effect of $\mathrm{N}$ in alleviating $\mathrm{Cd}$ stress is dose dependent and occurs through its promoting effect on chlorophyll synthesis as well as on the activities of antioxidant enzymes, such as SOD, catalase 
and peroxidase, which partially alleviated the accumulation of ROS [61]. Phosphorus application neutralizes the toxic effect of $\mathrm{Cd}$ by the dilution effect and increases plant growth and yield [12]. It was found that the application of phosphate fertilizers decreased the mobility of $\mathrm{Cd}$ in soil by changing mobile forms of $\mathrm{Cd}$ to the immobile form of $\mathrm{Cd}$ phosphate. The other mechanism shown for decreasing $\mathrm{Cd}$ stress is by the addition of $\mathrm{P}$ and increasing GSH content and prevented membrane damage [62]. Similarly, improving K nutrition of plants under stress has been shown to minimize the oxidative cell damage by reducing ROS formation during photosynthesis and inhibiting activation of oxygen radical generating NADPH oxidase [63] and the form of $\mathrm{K}$ applied plays a significant interaction with $\mathrm{Cd}$ in plants. The form of $\mathrm{K}$ applied has differential effect on $\mathrm{Cd}$ accumulation and Cd stress. In a study on spring wheat, Zhao et al. [64] have shown that there was a differential response of wheat to three sources of $\mathrm{K}$ (as $\mathrm{KNO}_{3}, \mathrm{~K}_{2} \mathrm{SO}_{4}$, and $\mathrm{KCl}$ at the rate of 55,110 and $166 \mathrm{mg} \cdot \mathrm{K} \cdot \mathrm{kg}^{-1}$ soil) applied under $\mathrm{Cd}$ stress (as $\mathrm{CdCl}_{2}$ at a uniform rate of $15 \mathrm{mg} \cdot \mathrm{Cd} \cdot \mathrm{kg}^{-1}$ soil). When the level of $\mathrm{K}$ addition increased from 0 to $55 \mathrm{mg} \cdot \mathrm{K} \cdot \mathrm{kg}^{-1}$ soil, the application of $\mathrm{KCl}$ and $\mathrm{K}_{2} \mathrm{SO}_{4}$ resulted in $60 \%-90 \%$ increase in $\mathrm{Cd}$ concentration in shoots, while the application of $\mathrm{KNO}_{3}$ only resulted in marginal increase in $\mathrm{Cd}$ concentration in shoots thus protecting plant root and shoot dry mass [64]. Availability of $\mathrm{K}$ protects mustard plants from $\mathrm{Cd}$ toxicity by reducing its availability thereby depressing $\mathrm{H}_{2} \mathrm{O}_{2}$ content and lipid peroxidation, and increasing the activity of antioxidative enzymes [65].

The up-regulation of S-assimilation pathway alleviates $\mathrm{Cd}$ toxicity and improves capacity of plants to survive in a Cd polluted environment [66]. Studies have indicated that both ATP-sulfurylase (ATPS) and serine acetyl transferase (SAT) played important roles in limiting Cd accumulation and enhancing Cd tolerance in Triticum aestivum [5], B. juncea [66], Arabidopsis [67]. Higher expression of ATPS activity has been shown necessary for the maintenance of optimal GSH levels required for the proper functioning of Ascorbate (AsA)-GSH cycle in mustard [6]. Anjum et al. [68] have reported that S applied at $40 \mathrm{mg} \cdot \mathrm{S} \cdot \mathrm{Kg}^{-1}$ soil to mustard resulted in reduced $\mathrm{Cd}$ toxicity by increasing leaf AsA and GSH content. It can be explained that the improved S nutrition may allow a more adequate plant defense response by synthesis of $\mathrm{S}$ defense compounds, such as GSH and phytochelatins. The induction of $\mathrm{S}$ metabolism by $\mathrm{Cd}$ has been described to involve a coordinated transcriptional regulation of genes for sulfate uptake and its assimilation as GSH and phytochelatins biosynthesis [69]. Induction of phytochelatins is one of the main detoxification strategies against $\mathrm{Cd}$ by chelating $\mathrm{Cd}$ ions and preventing its toxicity [70]. Astolfi et al. [71] have shown that S-deficient plant shows in- crease of ATPS, $O$-acetyl serine (OAS) thiol lyase activity under $100 \mu \mathrm{M}$ Cd-treated plants, which may be a part of the defense mechanism based on the production of phytochelatins and its biosynthesis is closely dependent on S metabolism. Sulfur assimilation is considered a crucial step for plant survival under Cd stress [72]. Cai et al. [73] reported that exogenously applied GSH significantly increased chlorophyll content, net photosynthetic rate, maximal photochemical efficiency of PSII and effective PSII quantum yield in Cd-exposed plants. Recently, Masood et al. [74] reported under Cd stress $\mathrm{S}$ helped in stress alleviation via ethylene signaling.

The increasing concentration of $\mathrm{Cd}$ in the external medium replaces $\mathrm{Ca}$ at the binding site by other heavy metal cations at the exterior surface of the plasma membrane, thereby increasing $\mathrm{Ca}$ requirement. Cadmium decreases $\mathrm{Ca}$ content because of the competition between $\mathrm{Cd}$ and $\mathrm{Ca}$ at both $\mathrm{Ca}$ channels [75] and intracellular $\mathrm{Ca}$ binding proteins [76]. Calcium reduces the $\mathrm{Cd}$ toxicity mainly by reducing its uptake and competing at the transport site and secondly through influencing various physiological processes. It has been reported that liming or alkaline medium reduces $\mathrm{Cd}$ uptake which is facilitated at low $\mathrm{pH}$. Alleviation of $\mathrm{Cd}$ toxicity by $\mathrm{Ca}$ supplementation occurs either by decreasing $\mathrm{Cd}$ uptake or by reducing $\mathrm{Cd}$ toxicity. In Arabidopsis seedlings, the content of $\mathrm{Cd}$ per gram fresh weight was reduced from $46.7 \mu \mathrm{g}$ to $17.4 \mu \mathrm{g}$ in the presence of $30 \mathrm{mM} \mathrm{Ca}$ [77] by reducing $\mathrm{Cd}$ uptake. Wang and Song [78] reported that $5 \mathrm{mM} \mathrm{CaCl}_{2}$ application reversed the Cd effects on the activity of SOD, catalase, glutathione peroxidase and APX and reversed the $\mathrm{Cd}$-induced decrease in fresh mass as well as the changes in lipid peroxidation in Trifolium repens. The enhanced Cd tolerance in Lactuca sativa by $4 \mathrm{mM} \mathrm{CaCl}_{2}$ was the result of increased expression of phytochelatin synthase gene under $0.05 \mathrm{mM} \mathrm{Cd}$ treated in Lactuca sativa plants [79].

Magnesium shows an interaction with $\mathrm{Cd}$ toxicity and its alleviation. In Mg-deficient shoot and root of rice seedlings contained higher $\mathrm{Cd}$ concentration [80]. However, further results suggested that the protective effect of $\mathrm{Mg}$ against $\mathrm{Cd}$ toxicity was primarily due to enhanced antioxidant status and not the inhibition of Cd uptake. In contrast, Abul Kashem and Kawai [81] have reported that $10 \mathrm{mM} \mathrm{Mg}$ alleviated the $0.25 \mu \mathrm{M} \mathrm{Cd}$ toxicity in Japanese mustard spinach plants and exhibited two-fold higher shoot growth with decreased shoot $\mathrm{Cd}$ concentration of $40 \%$. The Mg-induced $\mathrm{Cd}$ alleviation has been related to the expression of OsIRT1, OsZIP1, OsZIP3 genes of rice roots.

\subsection{Micro Nutrients}

Zinc is an important group of metal transporters in the ZIP (ZRT, IRTlike protein) family. ZIP transporters are 
plasma-membrane transport proteins induced both in roots and shoots of Arabidopsis under Zn-limiting conditions. They are thought to be involved in $\mathrm{Cd}$ uptake from soil into the root cell and also in transport of $\mathrm{Cd}$ from root-to-shoot [51]. Enhanced root metal uptake mediated by ZIP transporters seems to be a factor necessary for hyperaccumulation. However, this does not account for hyperaccumulation in the model species A. halleri and $T$. caerulescens [51]. It is suggested that the toxic effects of $\mathrm{Cd}$ may be prevented by $\mathrm{Zn}$ application. In the case of $T$. violacea, the only $\mathrm{Cd} / \mathrm{Zn}$ interaction observed was in the small-sized plants whereby plants supplied with $\mathrm{Cd}$ at 2 $\mathrm{mg} \cdot \mathrm{L}^{-1}$ accumulated $\mathrm{Zn}$ to $48.5 \mathrm{mg} \cdot \mathrm{kg}^{-1}$ in the leaves compared to $16.8 \mathrm{mg} \cdot \mathrm{kg}^{-1}$ in the control. However, when supplied with $\mathrm{Cd}$ at $5 \mathrm{mg} \cdot \mathrm{L}^{-1}$, only $12.8 \mathrm{mg} \cdot \mathrm{Zn} \cdot \mathrm{kg}^{-1}$ was accumulated in the leaves suggesting $\mathrm{Cd} / \mathrm{Zn}$ antagonism at $2 \mathrm{mg} \cdot \mathrm{Cd} \cdot \mathrm{L}^{-1}[82]$.

Iron helps in $\mathrm{Cd}$ alleviation by both limiting $\mathrm{Cd}$ uptake and translocation and by increasing plant growth, photosynthetic pigment accumulation and more intense light phase of photosynthesis. Iron has been shown to help plants in counteracting the negative effects of $\mathrm{Cd}$ by retaining both quantity and quality of chloroplast. In Cdtreated $(25,50,100,150 \mu \mathrm{M})$ almond seedlings, the decrease in Fe results in the decrease in ferredoxins necessary for the light-induced oxido-reduction process and reduction in chlorophyll content [83]. At moderate and high Fe levels $\left(1.89\right.$ and $\left.16.8 \mathrm{mg} \cdot \mathrm{L}^{-1}\right)$, plant height in rice increased under low $\mathrm{Cd}$ level $(0.1 \mathrm{mM})$, but decreased under high levels of Cd stress $(1.0$ and $5.0 \mathrm{mM})$. Qureshi et al. [84] observed that the supplementation of Indian mustard with $40 \mu \mathrm{M}$ Fe suppressed oxidative stress and helped in retention of chloroplasts and chlorophylls and stabilizing thylakoid complex under $\mathrm{Cd}$ stress.

Availability of $\mathrm{Mn}$ to plants decreases in the presence of Cd in soil. The Mn-mediated amelioration of Cd-induced root growth inhibition in maize seedlings has been shown to be associated with parallel reductions in Cd uptake [85]. In a study on lupine, Zornoza et al. [86] found that supplementation of $\mathrm{MnSO}_{4}$ to Cd-treated plants played a protective role in photosynthetic tissues against $\mathrm{Cd}$ stress and increased the antioxidant capacity of root together with high leaf $\mathrm{Mn}$ concentration. The effects of Mn starvation reducing $\mathrm{Cd}$ uptake and plant concentration indicated that this $\mathrm{Mn}-\mathrm{Cd}$ interaction was not due to true cation antagonism, but they share a common transport site or process [42]. Thus, the reduced $\mathrm{Cd}$ accumulation in the presence of Mn could be due to reduced Cd uptake at the transport level.

\subsection{Beneficial Nutrients}

Selenium (Se) at low concentration can exert beneficial functions in plants and $\mathrm{Cd}$ stress alleviation [87]. The protective effect of Se against $\mathrm{Cd}$ toxicity has been shown to be through the diversion in their binding from lowmolecular-mass proteins to high-molecular-mass and the property of Se to form complex with metal [88]. The presence of Se reduces the availability of Cd blocking them in insoluble compounds. The application of $2 \mu \mathrm{M}$ $\mathrm{Na}_{2} \mathrm{SeO}_{4}$ alleviates the effects of $600 \mu \mathrm{M} \mathrm{CdCl}_{2}$ on chloroplast ultrastructure and functioning in rape by modulating activity of antioxidant enzymes, such as SOD, catalase, glutathione peroxidase and APX [87]. In Cd-stressed wheat and rape plants, Se counterbalanced the $\mathrm{Cd}$-induced changes in nutrients, reduced the lipid peroxidation and exerted positive effects on the cell membrane stability. The $\mathrm{Cd}$ stress and the protective role of Se were most conspicuous in rape [89].

The effect of silicon $(\mathrm{Si})$ nutrition on Cd uptake, growth and photosynthesis in rice plants under low-level $\mathrm{Cd}$ stress has been shown to be dependent on its concentration and time of its addition. In plants treated with 2.5 $\mu \mathrm{M} \mathrm{Cd}$, the addition of $0.6 \mathrm{mM} \mathrm{Si}$ at $20 \mathrm{~d}$ increased chlorophyll fluorescence, while treatment with $0.2 \mathrm{mM}$ Si significantly increased photochemical quenching suggesting an increase in light-use-efficiency. Study on Brassica chinensis has shown that the addition of $1.5 \mathrm{mM} \mathrm{Si}$ significantly decreased $\mathrm{Cd}$ uptake and root-to-shoot transport in plants grown hydroponically with $0.5 \mathrm{mg} \cdot \mathrm{L}^{-1} \mathrm{Cd}$ and alleviated $\mathrm{Cd}$ toxicity through increase in the activity of catalase and APX [90]. Antioxidants act as a cooperative network, employing a series of redox reactions and are involved in quenching ROS. Moreover, the addition of $35 \mathrm{mM} \mathrm{Si}$ to a hydroponics solution containing $5 \mu \mathrm{M}$ $\mathrm{Cd}$ was found beneficial for the growth of young maize plants. The alleviation of the Cd-inhibitory effect on maize plants by $\mathrm{Si}$ was not due to exclusion of $\mathrm{Cd}$ from the plant, but due to increased cell-wall extensibility. Silicon promotes growth of rice plants through increasing cell wall extensibility and alleviates the low-level Cd toxicity by improving light-use-efficiency [30].

\section{Conclusion}

Mineral nutrition of crops is an essential component of our agricultural system. However, higher levels of $\mathrm{Cd}$ in soil alter the uptake and translocation of mineral nutrients elements, resulting in nutrient deficiencies, oxidative stress, and reduction in plant growth and development of agricultural crops. Sufficient availability of mineral nutrients competes with $\mathrm{Cd}$ for transporters and reduces $\mathrm{Cd}$ accumulation in plants. Also, the involvement of mineral nutrients in physiological and biochemical processes and molecular mechanisms regulating photosynthesis and antioxidants system accounts for the alleviation of $\mathrm{Cd}$ stress. Thus, the management of mineral nutrients may be a useful tool to alleviate Cd stress, and improved mineral nutrition may provide a strategy to reduce $\mathrm{Cd}$ toxicity and alleviate $\mathrm{Cd}$ stress. The mechanisms of nutrient 
uptake and accumulation associated with the growth responses in Cd-treated plants are not well characterized. The literature available is insufficient to fully understand the role of plant nutrients in $\mathrm{Cd}$ stress tolerance. Therefore, further research is required for a better understanding of the interactions between $\mathrm{Cd}$ and plant nutrients in soil-plant system.

\section{Acknowledgements}

Authors thank University Grants Commission, New Delhi and Council of Scientific \& Industrial Research, New Delhi for financial assistance.

\section{REFERENCES}

[1] L. S. di Toppi and R. Gabbrielli, "Response to Cadmium in Higher Plants," Environmental and Experimental Botany, Vol. 41, No. 2, 1999, pp. 105-130. doi:10.1016/S0098-8472(98)00058-6

[2] M. Vahter, M. Berglund, S. Slorach, L. Friberg, M. Sarić, X. Q. Zheng and M. Fujita, "Methods for Integrated Exposure Monitoring of Lead and Cadmium," Environmental Research, Vol. 56, No. 1, 1991, pp. 78-89. doi:10.1016/S0013-9351(05)80111-2

[3] A. Kabata-Pendias and H. Pendias, "Trace Elements in Soils and Plants," 3rd Edition, CRC Press, Boca Raton, 2001.

[4] S. Muramoto and I. Aoyama, "Effects of Fertilizers on the Vicissitude of Cadmium in Rice Plants," Journal of Environmental Science and Health, Vol. 25, No. 6, 1990, pp. 629-636.

[5] N. A. Khan, Samiullah, S. Singh and R. Nazar, "Activities of Antioxidative Enzymes, Sulphur Assimilation, Photosynthetic Activity and Growth of Wheat (Triticum aestivum) Cultivars Differing in Yield Potential under Cadmium Stress," Journal of Agronomy and Crop Science, Vol. 193, No. 6, 2007, pp. 435-444. doi:10.1111/j.1439-037X.2007.00272.X

[6] N. A. Khan, N. A. Anjum, R. Nazar and N. Iqbal, "Increased Activity of ATP-Sulfurylase and Increased Contents of Cysteine and Glutathione Reduce High Cadmium-Induced Oxidative Stress in Mustard Cultivar with High Photosynthetic Potential," Russian Journal of Plant Physiology, Vol. 56, No. 5, 2009, pp. 670-677. doi: $10.1134 / \mathrm{S} 1021443709050136$

[7] J. Feng, Q. Shi, X. Wang, M. Wei, F. Yang and H. Xu, "Silicon Supplementation Ameliorated the Inhibition of Photosynthesis and Nitrate Metabolism by Cadmium (Cd) Toxicity in Cucumis sativus L.," Scientia Horticulturae, Vol. 123, No. 4, 2010, pp. 521-530. doi:10.1016/j.scienta.2009.10.013

[8] M. A. Hossain, M. Hasanuzzaman and M. Fujita, "UpRegulation of Antioxidant and Glyoxalase Systems by Exogenous Glycinebetaine and Proline in Mung Bean Confer Tolerance to Cadmium Stress," Physiology and Molecular Biology of Plants, Vol. 16, No. 3, 2010, pp. 259-272. doi:10.1007/s12298-010-0028-4
[9] M. Mobin and N. A. Khan, "Photosynthetic Activity, Pigment Composition and Antioxidative Response of Two Mustard (Brassica juncea) Cultivars Differing in Photosynthetic Capacity Subjected to Cadmium Stress," Journal of Plant Physiology, Vol. 164, No. 5, 2007, pp. 601610. doi:10.1016/j.jplph.2006.03.003

[10] G. Shi, C. Liu, Q. Cai, Q. Liu and C. Hou, "Cadmium Accumulation and Tolerance of Two Safflower Cultivars in Relation to Photosynthesis and Antioxidantive Enzymes," Bulletin of Environmental and Contamination Toxicology, Vol. 85, No. 3, 2010, pp. 256-263. doi:10.1007/s00128-010-0067-0

[11] S. Brahim, D. Joke, C. Ann, N. Jean-Paul, T. Marjo, T. Arja, K. Sirpa, V. B. Frank, S. Karen and V. Jaco, "Leaf Proteome Responses of Arabidopsis thaliana Exposed to Mild Cadmium Stress," Journal of Plant Physiology, Vol. 167, No. 4, 2010, pp. 247-254. doi:10.1016/j.jplph.2009.09.015

[12] N. Sarwar, S. Saifullah, S. Malhi, M. H. Zia, A. Naeem, S. Bibi and G. Farida, "Role of Mineral Nutrition in Minimizing Cadmium Accumulation by Plants," Journal of the Science of Food and Agriculture, Vol. 90, No. 6, 2010, pp. 925-937.

[13] L. E. Williams, J. K. Pittman and J. L. Hall, "Emerging Mechanisms for Heavy Metal Transport in Plants," Biochimicia Biophysica Acta, Vol. 1465, No. 1-2, 2000, pp. 104-126. doi:10.1016/S0005-2736(00)00133-4

[14] C. A. F. De Sousa and L. Sodek, "Alanine Metabolism and Alanine Aminotransferase Activity in Soybean (Glycine max) during Hypoxia of the Root System and Subsequent Return to Normoxia," Environmenatl and Experimental Botany, Vol. 50, No. 1, 2003, pp. 1-8. doi:10.1016/S0098-8472(02)00108-9

[15] H. Obata, N. Inoue and M. Umebayashi, "Effect of Cd on Plasma Membrane ATPase From Plant Roots Differing in Tolerance to Cd," Soil Science and Plant Nutrition, Vol. 42, No. 2, 1996, pp. 361-366.

[16] S. A. Mouron, C. A. Grillo, F. N. Dulout and C. D. Golijow, "A Comparative Investigation of DNA Strand Breaks, Sister Chromatid Exchanges and K-Ras Gene Mutations Induced by Cadmium Salts in Cultured Human Cells," Mutation Research, Vol. 568, No. 1, 2004, pp. 221-231. doi:10.1016/j.mrfmmm.2004.08.012

[17] S. Ünyayar, A. G. Değer, A. Çelik, F. Ö. Çekiç and S. Çevik, "Cadmium-Induced Antioxidant Status and Sisterchromatid Exchanges in Vicia faba L.," Turkish Journal of Biology, Vol. 34, No. 4, 2010, pp. 413-422.

[18] D. Ueno, E. Koyama, I. Kono, T. Ando, M. Yano and J. F. $\mathrm{Ma}$, "Identification of a Novel Major Quantitative Trait Locus Controlling Distribution of Cd between Roots and Shoots in Rice," Plant Cell and Physiology, Vol. 50, No. 12, 2009, pp. 2223-2233. doi:10.1093/pcp/pcp160

[19] R. Blanvillain, J. H. Kim, S. Wu, A. Lima and D. W. Ow, "Oxidative Stress 3 Is a Chromatin-Associated Factor Involved in Tolerance to Heavy Metals and Oxidative Stress," The Plant Journal, Vol. 57, No. 3, 2009, pp. 654665. doi:10.1111/j.1365-313X.2008.03717.x

[20] N. Verbruggen, C. Hermans and H. Schat, "Molecular Mechanisms of Metal Hyperaccumulation in Plants," New 
Phytologist, Vol. 181, No. 4, 2009, pp. 759-776.

[21] V. Korenkov, K. Hirschi, J. D. C. Weld and G. J. Wagner, "Enhancing Tonoplast $\mathrm{Cd} / \mathrm{H}$ Antiport Activity Increases $\mathrm{Cd}, \mathrm{Zn}$, and $\mathrm{Mn}$ Tolerance, and Impacts Root/ Shoot Cd Partitioning in Nicotiana tabacum L.," Planta, Vol. 226, No. 6, 2007, pp. 1379-1387. doi: $10.1007 / \mathrm{s} 00425-007-0577-0$

[22] P. Hinsinger, C. Plassard and B. Jaillard, "Rhizosphere: A New Frontier for Soil Biogeochemistry," Journal Geochemical Exploration, Vol. 88, No. 1-3, pp. 210-213. doi:10.1016/j.gexplo.2005.08.041

[23] V. Pantazis, I. Kalavrouziotis and I. Deligiannakis, " $\mathrm{Cu}-$ Zn Accumulation on Soil Plant System Irrigated with Wastewater," Proceedings in IWA Facing Sludge Diversities: Challenges, Risks and Opportunities, Antalya, 2830 March 2007.

[24] M. Mench and E. Martin, "Mobilization of Cadmium and other Metals from Two Soils by Root Exudates of Zea mays L., Nicotiana tabacum L and Nicotiana rustica L.," Plant and Soil, Vol. 132, 1991, pp. 187-196.

[25] H. Marschner, "Mineral Nutrition of Higher Plants," 2nd Edition, Academic Press, London, 1995, pp. 405-435.

[26] A. Llamas, C. I. Ullrich and A. Sanz, " $\mathrm{Cd}^{2+}$ Effects on Transmembrane Electrical Potential Difference, Respiration and Membrane Permeability of Rice (Oryza sativa L.) Roots," Plant and Soil, Vol. 219, No. 1-2, 2000, pp. 2128. doi:10.1023/A:1004753521646

[27] L. Perfus-Barbeoch, N. Leonhardt, A. Vavasseur and C. Forestier, "Heavy Metal Toxicity: Cadmium Permeates through Calcium Channels and Disturbs the Plant Water Status," Plant Journal, Vol. 32, No. 4, 2002, pp. 539-548. doi:10.1046/j.1365-313X.2002.01442.x

[28] A. Göthberg, M. Greger, K. Holm and B. E. Bengtsson, "Influence of Nutrient Levels on Uptake and Effects of Mercury, Cadmium, and Lead in Water Spinach," Journal of Environmental Quality, Vol. 33, No. 4, 2004, pp. 12471255. doi:10.2134/jeq2004.1247

[29] J. Y. Sun and Z. G. Shen, "Effects of Cd Stress on Photosynthetic Characteristics and Nutrient Uptake of Cabbages with Different Cd-Tolerance," Chinese Journal of Applied Ecology, Vol. 18, No. 11, 2007, pp. 2605-2610.

[30] C. C. Nwugo and A. J. Huerta, "Silicon-Induced Cadmium Resistance in Rice (Oryza sativa)," Journal of Plant Nutrition and Soil Science, Vol. 171, No. 6, 2008, pp. 841-848. doi:10.1002/jpln.200800082

[31] H. Obata and M. Umebayashi, "Effects of Cadmium on Mineral Nutrient Concentrations in Plants Differing in Tolerance for Cadmium," Journal of Plant Nutrition, Vol. 20, No. 1, 1997, pp. 97-105. doi:10.1080/01904169709365236

[32] M. Gussarson and P. Jensen, "Effects of Copper and Cadmium on Uptake and Leakage of $\mathrm{K}^{+}$in Birch (Betula pendula) Roots," Tree Physiology, Vol. 11, No. 3, 1992, pp. 305-313.

[33] M. Rezvani, F. Zaefarian, M. Miransari and G. A. Nematzadeh, "Uptake and Translocation of Cadmium and Nutrients by Aeluropus littoralis," Archives of Agronomy and Soil Science, 2011. doi:10.1080/03650340.2011.591385

[34] R. Aina, M. Labra, P. Fumagalli, C. Vannini, M. Marsoni, U. Cucchi, M. Bracale, S. Sgorbati and S. Citterio, "ThiolPeptide Level and Proteomic Changes in Response to Cadmium Toxicity in Oryza sativa L. Roots," Environmental and Experimental Botany, Vol. 59, No. 3, 2007, pp. 381-392. doi:10.1016/j.envexpbot.2006.04.010

[35] J. F. Gonçalves, F. G. Antes, J. Maldanera, L. B. Pereira, L. A. Tabaldi, R. Rauber, L. V. Rossato, D. A. Bisognin, V. L. Dressler, É. M. de M. Flores and F. T. Nicoloso, "Cadmium and Mineral Nutrient Accumulation in Potato Plantlets Grown under Cadmium Stress in Two Different Experimental Culture Conditions," Plant Physiology and Biochemistry, Vol. 47, No. 10, 2009, pp. 814-821. doi:10.1016/j.plaphy.2009.04.002

[36] M. L. Guerinot, "The ZIP Family of Metal Transporters," Biochimica Biophysica Acta, Vol. 1465, No. 1-2, 2000, pp. 190-198. doi:10.1016/S0005-2736(00)00138-3

[37] J. Dong, F. Wu and G. Zhang, "Influence of Cadmium on Antioxidant Capacity and Four Microelement Concentrations in Tomato Seedlings (Lycopersicon esculentum)," Chemosphere, Vol. 64, No. 10, 2006, pp. 1659-1666. doi:10.1016/j.chemosphere.2006.01.030

[38] F. Van Assche and H. Clijsters, "Effects of Metals on Enzyme Activity in Plants," Plant Cell Environment, Vol. 13, No. 3, 1990, pp. 195-206. doi:10.1111/j.1365-3040.1990.tb01304.x

[39] T. Yoshihara, H. Hodoshima, Y. Miyano, K. Shoji, H. Shimada and F. Goto, "Cadmium Inducible Fe Deficiency Responses Observed from Macro and Molecular Views in Tobacco Plants," Plant Cell Report, Vol. 25, No. 4, 2006, pp. 365-373. doi:10.1007/s00299-005-0092-3

[40] M. Ebadi, M. P. Leuschen, H. El Refaey, F. M. Hamada, and P. Rojas, "The Antioxidant Properties of Zinc and Metallothionein," Neurochemistry International, Vol. 29, No. 2, 1996, pp. 159-166. doi:10.1016/0197-0186(95)00116-6

[41] H. Wu, C. Chen, J. Du, H. Liu, Y. Cui, Y. Zhang, Y. He, J. Li, Z. Feng, Y. Wang, C. Chu and H. Q. Ling, "CoOverexpression FIT with AtbHLH38 or AtbHLH39 in Arabidopsis Enhanced Cadmium Tolerance via Increased Cadmium Sequestration in Roots and Improved Iron Homeostasis of Shoots," Plant Physiology, Vol. 158, No. 2, 2011, pp. 790-800. doi:10.1104/pp.111.190983

[42] K. Peng, C. Luo, W. You, Ch. Lian, X. Li and Z. Shen, "Manganese Uptake and Interactions with Cadmium in the Hyperaccumulator Phytolacca americana L.," Journal of Hazardous Material, Vol. 154, No. 1-3, 2008, pp. 674-681. doi:10.1016/j.jhazmat.2007.10.080

[43] L. Cai and G. Cherian, "Zinc-Metallothionein Protects from DNA Damage Induced by Radiation Better than Glutathione and $\mathrm{Cu}$ - or Cd-Metallothioneins," Toxicology Letters, Vol. 136, No. 3, 2003, pp. 193-198. doi:10.1016/S0378-4274(02)00359-4

[44] U. Roth, E. V. Roepenack-Lahaye and S. Clemens, "Proteome Changes in Arabidopsis thaliana Roots upon Eexposure to $\mathrm{Cd}^{2+}$," Journal of Experimental Botany, Vol. 57, No. 15, 2006, pp. 4003-4013. doi:10.1093/jxb/erl170

[45] A. Papoyan and L. V. Kochian, "Identification of Thlaspi 
caerulescens Genes That May Be Involved in Heavy Metal Hyperaccumulation and Tolerance. Characterization of a Novel Heavy Metal Transporting ATPase," Plant Physiology Vol. 136, No. 3, 2004, pp. 3814-3823. doi:10.1104/pp.104.044503

[46] D. E. Salt, R. C. Prince, I. J. Pickering and I. Raskin, "Mechanisms of Cadmium Mobility and Accumulation in Indian Mustard," Plant Physiology, Vol. 109, No. 4, 1995, pp. 1427-1433.

[47] M. P. Benavides, S. M. Gallego and M. L. Tomaro, "Cadmium Toxicity in Plants," Brazilian Journal of Plant Physiology, Vol. 17, No. 1, 2005, pp. 21-34. doi:10.1590/S1677-04202005000100003

[48] A. Polle and A. Schutzendubel, "Heavy Metal Signaling in Plants: Linking Cellular and Organismic Responses," In: H. Hirt and K. Shinozaki, Eds., Plant Responses to Abiotic Stress, Springer-Verlag, Berlin, pp. 187-215.

[49] Y. Nevo and N. Nelson, "The NRAMP Family of MetalIon Transporters," Biochimicia Biophyscia Acta, Vol. 1763, No. 7, 2006, pp. 609-620. doi:10.1016/j.bbamcr.2006.05.007

[50] C. K. E. Wong and C. S. Cobbett, "HMA P-Type ATPases Are the Major Mechanism for Root-to-Shoot Cd Translocation in Arabidopsis thaliana," New Phytologist Vol. 181, No. 1, 2009, pp. 71-78. doi:10.1111/j.1469-8137.2008.02638.x

[51] U. Krämer, I. N. Talke and M. Hanikenne, "Transition Metal Transport," FEBS Letter, Vol. 581, No. 12, 2007, pp. 2263-2272. doi:10.1016/j.febslet.2007.04.010

[52] C. Bernard, N. Roosens, P. Czernic, M. Lebrun and N. Verbruggen, "A Novel CPx-ATPase from the Cadmium Hyperaccumulator Thlaspi caerulescens," FEBS Letter, Vol. 569, No. 1-3, 2004, pp. 140-148. doi:10.1016/j.febslet.2004.05.036

[53] Y. O. Korshunova, D. Eide, W. G. Clark, M. L. Guerinot, and H. B. Pakrasi, "The IRT1 Protein from Arabidopsis thaliana Is a Metal Transporter with a Broad Substrate Range," Plant Molecular Biology, Vol. 40, No. 1, 1999 , pp. 37-44. doi:10.1023/A:1026438615520

[54] G. Vert, N. Grotz, F. Dédaldéchamp, F. Gaymard, M. L. Guerinot, J. F. Briat and C. Curie, "IRT1, an Arabidopsis Transporter Essential for Iron Uptake from the Soil and for Plant Growth," The Plant Cell, Vol. 14, No. 6, 2002, pp. 1223-1233. doi:10.1105/tpc.001388

[55] B. Montanini, D. Blaudez, S. Jeandroz, D. Sanders and M. Chalot, "Phylogenetic and Functional Analysis of the Cation Diffusion Facilitator (CDF) Family: Improved Signature and Prediction of Substrate Specificity," BMC Genomics, Vol. 107, No. 8, 2007, pp. 23-107.

[56] S. Thomine, F. Lelievre, E. Debarbieux, J. I. Schroeder and H. Barbier-Brygoo, "AtNRAMP3, a Multispecific Vacuolar Metal Transporter Involved in Plant Rresponses to Iron Deficiency," The Plant Journal, Vol. 34, No. 5, 2003, pp. 685-695. doi:10.1046/j.1365-313X.2003.01760.x

[57] D. Pankovic, M. Plesnicar, I. Arsenijeevic-Maksimovic, N. Petrovic, Z. Sakac and R. Kastori, "Effects of Nitrogen Nutrition on Photosynthesis in Cd-Treated Sunflower Plants" Annals of Botany, Vol. 86, No. 4, 2000, pp. 841-

\section{7. doi:10.1006/anbo. 2000.1250}

[58] M. A. Jalloh, J. Chen, F. Zhen and G. Zhang, "Effect of Different N Fertilizer Forms on Antioxidant Capacity and Grain Yield of Rice Growing under Cd Stress," Journal of Hazardous Material, Vol. 162, No. 2-3, 2009, pp. 10811085. doi:10.1016/j.jhazmat.2008.05.146

[59] S. S. Sharma and K. J. Dietz, "The Significance of Amino Acids and Amino Acid-derived Molecules in Plant Responses and Adaptation to Heavy Metal Stress," Journal of Experimental Botany, Vol. 57, No. 4, 2006, pp. 711726. doi:10.1093/jxb/erj073

[60] E. Zhu, D. Liu, J. G. Li, T. Q. Li, X. E. Yang, Z. L. He and P. J. Stoffella, "Effect of Nitrogen Fertilizer on Growth and Cadmium Accumulation in Sedum alfredii Hance," Journal of Plant Nutrition, Vol. 34, 2011, pp. $115-126$

[61] T. Lin, X. Zhu, F. Zhang and X. Wan, "The Detoxification Effect of Cadmium Stress in Populus yunnanensis," Research Journal of Botany, Vol. 4, No. 1, 2011, pp. 1319.

[62] H. Wang, S. C. Zhao, R. L. Liu, W. Zhou and J. Y. Jin, "Changes of Photosynthetic Activities of Maize (Zea mays L.) Seedlings in Response to Cadmium Stress," Photosynthetica, Vol. 47, No. 2, 2009, pp. 277-283. doi:10.1007/s11099-009-0043-2

[63] W. Shen, K. Nada and S. Tachibana, "Involvement of Polyamines in the Chilling Tolerance of Cucumber Cultivars," Plant Physiology, Vol. 124, No. 1, 2000, pp. 431439.

[64] Z. Q. Zhao, Y. G. Zhu, H. Y. Li, S. E. Smith and F. A. Smith, "Effects of Forms and Rates of Potassium Fertilizers on Cadmium Uptake by Two Cultivars of Spring Wheat (Triticum aestivum L.)," Environmental International, Vol. 29, No. 7, 2004, pp. 973-978. doi:10.1016/S0160-4120(03)00081-3

[65] S. Umar, I. Diva, N. A. Anjum and M. Iqbal, "Research Findings II: Potassium Nutrition Reduces Cadmium Accumulation and Oxidative Burst in Mustard (Brassica campestris L.)," e-ifc 2008, No. 16.

[66] A. L. Wangeline, J. L. Burkhead, K. L. Hale, S. D. Lindblom, N. Terry, M. Pilon and E. A. H. Pilon-Smits, "OverExpression of ATP Sulfurylase in Indian Mustard: Effects on Tolerance and Accumulation of Twelve Metals," Journal of Environmental Quality, Vol. 33, No. 1, 2004, pp. 54-60. doi:10.2134/jeq2004.0054

[67] J. R. Howarth, J. R. Domínguez-Solís, G. Gutíerrez-Alcalá, J. L. Wray, L. C. Romero and C. Gotor, "The Serine Acetyltransferase Gene Family in Arabidopsis thaliana and the Regulation of Its Expression by Cadmium," Plant Molecular Biology, Vol. 51, No. 4, 2003, pp. 589-598. doi:10.1023/A:1022349623951

[68] N. A. Anjum, S. Umar, A. Ahmad, M. Iqbal and N. A. Khan, "Sulphur Protects Mustard (Brassica campestris L.) from Cadmium Toxicity by Improving Leaf Ascorbate and Glutathione," Plant Growth Regulation, Vol. 54, No. 3, 2008, pp. 271-279. doi:10.1007/s10725-007-9251-6

[69] F. F. Nocito, C. Lancilli, B. Crema, P. Fourcroy, J.-C. Davidian and G. A. Sacchi, "Heavy Metal Stress and Sulfate Uptake in Maize Roots," Plant Physiology, Vol. 141, No. 
3, 2006, pp. 1138-1148. doi:10.1104/pp.105.076240

[70] Z. C. Zhang, B. X. Chen and B. S. Qiu, "Phytochelatin Synthesis Plays a Similar Role in Shoots of the Cadmium Hyperaccumulator Sedum alfredii as in Non-Resistant Plants," Plant Cell Environment, Vol. 33, No. 8, 2010, pp. 1248-1255. doi:10.1111/j.1365-3040.2010.02144.x

[71] S. Astolfi, S. Zuchi and C. Passera, "Role of Sulphur Availability on Cadmium-Induced Changes of Nitrogen and Sulphur Metabolism in Maize (Zea mays L.) Leaves," Journal of Plant Physiology, Vol. 161, No. 7, 2004, pp. 795-802. doi:10.1016/j.jplph.2003.11.005

[72] S. S. Gill and N. Tuteja, "Cadmium Stress Tolerance in Crop Plants. Probing the Role of Sulfur," Plant Signaling and Behavior, Vol. 6, No. 2, 2011, pp. 215-222. doi:10.4161/psb.6.2.14880

[73] Y. Cai, F. Cao, W. Cheng, G. Zhang and F. Wu, "Modulation of Exogenous Glutath1ione in Phytochelatins and Photosynthetic Performance Against Cd Stress in the Two Rice Genotypes Differing in Cd Tolerance," Biological Trace Element Research, Vol. 143, No. 2, 2010, pp. 11591173. doi:10.1007/s12011-010-8929-1

[74] A. Masood, N. Iqbal and N. A. Khan, "Role of Ethylene in Alleviation of Cadmium-Induced Photosynthetic Capacity Inhibition by Sulfur in Mustard," Plant Cell Environment Vol. 35, No. 3, 2012, pp. 524-533. doi:10.1111/j.1365-3040.2011.02432.x

[75] M. T. Nelson, "Interactions of Divalent Cations with Single Calcium Channels from Rat Brain Synaptosomes," Journal of General Physiology, Vol. 87, No. 2, 1986, pp. 201-222. doi:10.1085/jgp.87.2.201

[76] A. Rivetta, N. Negrini and M. Cocucci, "Involvement of $\mathrm{Ca}^{2+}$ Calmodulin in $\mathrm{Cd}^{2+}$ Toxicity during the Early Phases of Radish (Raphanus sativus L.) Seed Germination," Plant Cell Environment, Vol. 20, No. 5, 1997, pp. 600608. doi:10.1111/j.1365-3040.1997.00072.x

[77] N. Suzuki, "Alleviation by Calcium of Cd-Induced Root Growth Inhibition in Arabidopsis Seedling," Plant Biotechnology, Vol. 22, 2005, pp. 19-25.

[78] Q. C. Wang and H. Song, "Calcium Protects Trifolium repens L. Seedlings against Cadmium Stress," Plant Cell Reports, Vol. 28, No. 9, 2009, pp. 1341-1349. doi:10.1007/s00299-009-0734-y

[79] H. E. Zhenyan, L. I. Jiangchuan, H. Zhang and M. I. Ma, "Different Effects of Calcium and Lanthanum on the Expression of Phytochelatin Synthase Gene and Cadmium Absorption in Lactuca sativa," Plant Science, Vol. 168, No. 2, 2005, pp. 309-318. doi:10.1016/j.plantsci.2004.07.001

[80] T. S. Chou, Y. Y. Chao, W. D. Huang, C. Y. Hong and C. H. Kao, "Effect of Magnesium Deficiency on Antioxidant Status and Cadmium Toxicity in Rice Seedlings," Journal of Plant Physiology, Vol. 168, No. 10, 2011, pp. 10211030. doi:10.1016/j.jplph.2010.12.004

[81] M. D. A. Kashem and S. Kawai, "Alleviation of Cadmium Phytotoxicity by Magnesium in Japanese Mustard Spinach," Soil Science and Plant Nutrition, Vol. 53, No. 3, 2007, pp. 246-251. doi:10.1111/j.1747-0765.2007.00129.x

[82] R. A. Street, M. G. Kulkarni, W. A. Stirk, C. Southway, and J. Van Staden, "Effect of Cadmium on Growth and Micronutrient Distribution in Wild Garlic (Tulbaghia violacea)," South African Journal of Botany, Vol. 76, No. 2, 2010, pp. 332-336. doi:10.1016/j.sajb.2009.12.006

[83] E. Nada, B. A. Ferjani, R. Ali, B. R. B. M. Imed and B. Makki, "Cadmium-Induced Growth Inhibition and Alteration of Biochemical Parameters in Almond Seedlings Grown in Solution Culture," Acta Physilogiae Plantarum, Vol. 29, No. 2, 2007, pp. 57-62. doi:10.1007/s11738-006-0009-y

[84] M. I. Qureshi, G. M. D’Amici, M. Fagioni, S. Rinalducci and L. Zolla, "Iron Stabilizes Thylakoid Protein-Pigment Complexes in Indian Mustard during Cd-Phytoremediation as Revealed by BN-SDS-PAGE and ESI-MS/MS," Journal of Plant Physiology, Vol. 167, No. 10, 2010, pp. 761-770. doi:10.1016/i.jplph.2010.01.017

[85] P. Pal'ove-Balang, A. Kisová, J. Pavlovkin and I. Mistrík, "Effect of Manganese on Cadmium Toxicity in Maize Seedlings," Plant Soil and Environment, Vol. 52, No. 4, 2006, pp. 143-149.

[86] P. Zornoza, B. Sánchez-Pardo and R. R. O. Carpena, "Interaction and Accumulation of Manganese and Cadmium in the Manganese Accumulator Lupinus albus," Journal of Plant Physiology, Vol. 167, No. 13, 2010, pp. 1027 1032. doi:10.1016/j.jplph.2010.02.011

[87] M. Filek, R. Keskinen, H. Hartikainen, I. Szarejko, A. Janiak, Z. Miszalski and A. Golda, "The Protective Role of Selenium in Rape Seedlings Subjected to Cadmium Stress," Journal of Plant Physiology, Vol. 165, No. 8, 2008, pp. 833-844. doi:10.1016/j.jplph.2007.06.006

[88] P. D. Whanger, "Selenium in the Treatment of Heavy Metal Poisoning and Chemical Carcinogenesis," Journal of Trace Element Electrolytes in Health and Disease, Vol. 6, No. 6, 1992, pp. 209-221.

[89] M. Zembala, M. Filek, S. Walas, H. Mrowiec, A. Kornaś, Z. Miszalski and H. Hartikainen, "Effect of Selenium on Macro- and Microelement Distribution and Physiological Parameters of Rape and Wheat Seedlings Exposed to Cadmium Stress," Plant Soil, Vol. 329, No. 1, 2010, pp. 457-468. doi:10.1007/s11104-009-0171-2

[90] A. Song, Z. Li, J. Zhang, G. Xue, F. Fan and Y. Liang, "Silicon-Enhanced Resistance to Cadmium Toxicity in Brassica chinensis L. Is Attributed to Si-suppressed Cadmium Uptake and Transport and Si-Enhanced Antioxidant Defense Capacity," Journal of Hazardous Material, Vol. 172, No. 1, 2009, pp. 74-83. doi:10.1016/j.jhazmat.2009.06.143

[91] D. Pankovic, M. Plesnicar, I. Arsenijeevic-Maksimovic, N. Petrovic, Z. Sakac and R. Kastori, "Effects of Nitrogen Nutrition on Photosynthesis in Cd-Treated Sunflower Plants," Annals of Botany, Vol. 86, No. 4, 2000, pp. 841847. doi:10.1006/anbo.2000.1250

[92] T. Landberg and M. Greger, "Influence of N and N Supplementation on Cd Accumulation in Wheat Grain," 7th International Conference on the Biogeochemistry of Trace Elements, Uppsala '03, Uppsala, 15-19 June 2003, pp. 90-91.

[93] C. R. F. S. Soares, J. O. Oswaldo, J. G. de Carvalho and R. G. Guilherme, "Phosphate Nutrition and Arbuscular 
Mycorrhiza on Amelioration of Cadmium Toxicity in Trema [Trema micrantha (L.) Blum.]," Revista Árvore, Vol. 31, No. 5, 2007, pp. 783-792. doi:10.1590/S0100-67622007000500002

[94] M. J. Hassan, Z. Zhu, B. Ahmad and Q. Mahmood, "Influence of Cadmium Toxicity on Rice Genotypes as Affected by Zinc, Sulfur and Nitrogen Fertilizers," Caspian
Journal of Environmental Sciences, Vol. 4, No. 1, 2006, pp. 1-8.

[95] M. Choudhary, L. D. Bailey, C. A. Grant and D. Leisle, "Effect of $\mathrm{Zn}$ on the Concentration of $\mathrm{Cd}$ and $\mathrm{Zn}$ in Plant Tissue of Two Durum Wheat Lines," Canadian Journal of Plant Science, Vol. 75, No. 2, 1995, pp. 445-448. doi:10.4141/cjps95-074 